Rapid Reviews COVID-19

\title{
Reviews of "GRP78 binds SARS-CoV-2 Spike protein and ACE2 and GRP78 depleting antibody blocks viral entry and infection in vitro"
}

Abdo Elfiky ${ }^{1}$, Ahmed Ezat ${ }^{2}$, Ivo Sirakov ${ }^{3}$

${ }^{1}$ Cairo University Faculty of Science, Biophysics, Egypt,

${ }^{2}$ Biophysics Department, Faculty of Science, Cairo University, Giza, Egypt,

${ }^{3}$ Medical University of Sofia: Medicinski universitet-Sofia, Medical microbiology, Bulgaria

Published on: Jun 17, 2021

License: Creative Commons Attribution 4.0 International License (CC-BY 4.0). 
Since our solicitation of reviews, this preprint has been published in the Journal of Biological Chemistry and the link to the published manuscript can be found here.

To read the original manuscript, click the link above.

Summary of Reviews: This preprint demonstrates that GRP78 is an important cofactor for the interaction of SARS-CoV-2 Spike protein and ACE2 on the cell surface and provides evidence to support the therapeutic potential of targeting GRP78. Reviewers deem these conclusions reliable.

\section{Reviewer 1 (Abdo Elfiky, Ahmed Ezat) | प्राप्र}

\section{Reviewer 2 (Ivo Sirakov) | प्र०ण}

$$
\begin{aligned}
& \text { RR:C19 Strength of Evidence Scale Key } \\
& \text { प प्र०प = Misleading }
\end{aligned}
$$

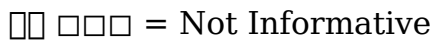

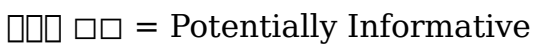

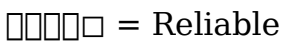

$$
\begin{aligned}
& \text { प्राप्र }=\text { Strong }
\end{aligned}
$$

To read the reviews, click the links below. 